\title{
Editorial
}

\section{Developing Successful Transition Support for Students in Africa: The Role of Academic Advising}

\author{
Birgit Schreiber ${ }^{\mathrm{i}}$,Thierry M. Luescher ${ }^{\mathrm{ii}} \&$ Teboho Moja ${ }^{\mathrm{iii}}$
}

The demand for professional student support and transition programmes is increasing unabatedly while higher education in Africa proceeds on its trajectory of rapid expansion and massification even in the context of the changing circumstances presented by the ongoing Covid-19 pandemic. At the same time as participation in higher education widens, there is also increased pressure for efficiency, relevance, and success, to ensure that students are equipped with relevant knowledge, skills, and competencies, develop personally and socio-culturally, and succeed academically, by making successful transitions into and through higher education and into the world of work and livelihoods. An evidence-based development of high-impact interventions using multiple methods, including student engagement surveys and action research approaches, is a proven strategy (Strydom et al., 2016). The development of context-relevant, high impact cocurricular programmes, support services and interventions by means of a reflective scholarship of Student Affairs and Services (SAS), institutional research and reflective practice, is also an imperative in the professionalisation of SAS in Africa.

Transition support for students with various identities and the intersectionality of their identities with other factors such as coming from disadvantaged backgrounds, being first-

i. Dr Birgit Schreiber is a member of the Africa Centre for Transregional Research at Alberts-Ludwig Universität Freiburg, Germany, and the Vice-President of IASAS and a member of the JSAA Editorial Executive. She is a Senior Consultant for Higher Education Leadership and Management. ORCid: 0000-0003-2469-0504. Email: birgitdewes@gmail.com

ii Prof. Thierry M. Luescher is the Research Director for Post-schooling and Work in the Inclusive Economic Development Division of the Human Sciences Research Council (HSRC), Cape Town, South Africa, and Associate Professor: Higher Education affiliate to the University of the Free State, Mangaung, South Africa. ORCid:0000-0002-6675-0512.Email:tluescher@hsrc.ac.za

iii. Prof. Teboho Moja is Clinical Professor of Higher Education, New York University, U.S.A. She is also a Visiting Research Fellow at the Centre for the Advancement of Scholarship, University of Pretoria, South Africa, and an Extraordinary Professor at the Institute of Post-School Studies, University of the Western Cape, South Africa. She is JSAA's Editor-in-chief. ORCid: 0000-0001-6343-3020.Email: teboho.moja@nyu.edu 
generation students, and living with a range of visible and non-visible disabilities, is particularly important. Transition programmes and services include orientation programmes, mentoring and related support initiatives (like peer support), tutoring, academic advising, supplemental instruction, and career guidance, to mention but a few (Smith, 2021). Transition support addresses equity issues and provides students the opportunities needed to succeed. This is the role that Student Affairs plays to directly impact on student development and success, levelling the playing ground for students from varied backgrounds, and helping to advance towards students' goals and aspirations. In the process, Student Affairs contributes to the achievement of targets set at national and institutional levels for expected throughput and success rates.

Much of the emphasis in student transitions literature and practice tends to be on students' point of entry into higher education and the first year, however, it is important to see students' lifecycle as a series of transitions, stages and phases. While many models sequentialize this process, we want to acknowledge the complexity and phases that students move through during a transition: perhaps revisiting certain phases, lingering longer in some while swiftly moving through others, exiting and entering and progressing at individual paces, depending on context and many criteria and their intersection. A way of conceptualizing student life cycles and illustrating transitions is offered by Michelle Morgan's "student experience transitions practitioner model". This model involves six stages and transitions: (1) first contact and admission $\rightarrow$ (2) pre-arrival $\rightarrow$ (3) arrival and orientation $\rightarrow$ (4) introduction to study at university $\rightarrow$ (5) re-orientation and re-introduction (6) outduction back to (1) first contact and admission (Morgan, 2016; Luescher, 2017). As Luescher (2017, p. 14) argued elsewhere:

"[By means of student life-cycle models] it is possible to ask quite deep and refined questions of what students from different backgrounds expect at different stages in the student life cycle, and how the higher education system, institutions, and academic and student affairs can respond to those expectations: to anticipate them and meet students at their point of need; to exceed their expectations; or to manage expectations by either creating them or moderating them in line with the available resources. The student life cycle models alert us that student life starts at the aspirational stage; that is before a student actually is a student. Different students move through the first year experience quite differently, encountering different kinds of 'trauma' and excitement and having different capabilities for navigating academic, social and personal struggles. Complex life cycle models conceptualise different stages and transitions in ways that allow for theoretically sound, evidence-based policy making and intervention, at all levels, with reference to dimensions or themes such as finance, teaching and learning, support, and employment.” (Luescher, 2017, p. 14)

There is a growing knowledge base in African and international literature on transitions in the first year and the first-year experience to which the JSAA has contributed greatly over the years inter alia with two guest-edited issues on the first-year student experience in 2016 
(JSAA, Volume 4 Issue 1) and in 2018 (JSAA, Volume 6 Issue 1). Student transitions have been an important topic in at least ten articles published by JSAA in the past, including most recently the research article by Annsilla Nyar titled “The 'Double Transition' for First-Year Students: Understanding the Impact of Covid-19 on South Africa's First-Year University Students" published in the JSAA Covid-19 Special Issue of 2021 (Nyar, 2021). The knowledge base on transitions must also include research into students' transitions into the correct study programmes; into and through students' senior years and to graduation; and eventually into employment (Getachew \& Daniel, 2016; Maree \& Molepo, 2004; Young, 2016). Academic advising and career guidance play important roles in this respect (Getachew \& Daniel, 2016; Janeke, 2021; Smith, 2021; Strydom et al., 2016).

\section{Academic Advising}

Notions and practices of academic advising have proliferated over the past decades in higher education, not only here on the African continent but also abroad. In literature on student transitions, academic advising is seen as an effective strategy to support students in overcoming obstacles towards academic success not only by providing academic support but often also non-academic support (Ogude et al., 2012; Smith, 2021; Strydom et al., 2016; Fussy, 2018).

Academic advising is defined as

[...] a series of intentional interactions with a curriculum, a pedagogy, and a set of student learning outcomes. Academic advising synthesizes and contextualizes students' educational experiences within the frameworks of their aspirations, abilities and lives to extend learning beyond campus boundaries and timeframes (NACADA, 2006, p.10).

With their work as guest-editors of this issue, François Strydom and Gugu Tiroyabone have opened up the conceptual and praxis field on academic advising for Student Affairs in Africa. This work is supported by and focussed on the South African Department of Higher Education and Training's national project on academic advising. The first seven articles in this issue are specifically focused on academic advising and offer case studies, critical discussions, and reviews, on this high-impact practice in higher education.

In addition to the articles on academic advising, there is also a set of articles that deals with a wider variety of themes to keep the JSAA lens as wide and diverse as possible. We start with a case study by Disaapele Mogashana and Moses Basitere of psychosocial support provided within an extended curriculum programme. Robert Kaniki takes the focus to China where he reviews the role of SAS in the cultural experience of international students. The next article explores the barriers and enablers experienced by a range of students in utilising 
counselling services, see Sefotho as well as Pitsoane's article. Discussions of student elections by Kwaku Abrefa Busi, Alice Amegah and Francis Arthur-Holmes is followed by an exploratory study around career choices by Chinaza Uleanya, Mofoluwake O. Uleanya, Gedala M. Naidoo, and Yasmin Rugbeer. The issue ends with Hettie Terblanche, Henry Mason and Barend van Wyk's study of first-year students experiences of attending a programme on developing mindsets.

\section{An Expanded JSAA Editorial Board and Structure}

The move of the journal from the University of Stellenbosch to the University of Pretoria as its host institution earlier this year has come with a number of innovations. First and foremost, we are proud to announce a group of new editors that join the journal. The new section editors are:

- Dr Angelina Wilson Fadiji, Senior Lecturer: Educational Psychology, University of Pretoria, South Africa;

- Dr Henry Mason, Directorate: Student Development and Support, Tshwane University of Technology, South Africa;

- Dr Annsilla Nyar, Director: South African National Resource Centre for the First-Year Experience and Students in Transition (SANRC), University of Johannesburg, South Africa;

- Dr Vicki Trowler, Post-doctoral Research Assistant: Pedagogic Research, Department of Chemical Sciences, School of Applied Sciences, University of Huddersfield, United Kingdom; and,

- Dr Angelique Wildschut, Chief Research Specialist: Post-schooling and Work, Human Sciences Research Council, Cape Town, South Africa.

They are joining the existing team of editors made up of:

- Prof. Teboho Moja, Professor of Higher Education, New York University; Extraordinary Professor of Higher Education, University of the Western Cape, South Africa;

- Dr Birgit Schreiber, Africa Centre for Transregional Research, Alberts-LudwigUniversität Freiburg, Germany; USAf Higher Education Leadership and Management; Vice-President: International Association of Student Affairs and Services;

- Prof.Thierry M. Luescher, Ph.D., Research Director: Post-schooling and Work, Human Sciences Research Council, Cape Town; Affiliate Associate Professor of Higher Education, University of the Free State, South Africa;

- Dr Bekele Workie Ayele, Senior Lecturer and Dean: Teacher Education, College 
of Education and Behavioral Sciences, Kotebe Metropolitan University, Addis Ababa, Ethiopia;

- Dr Martin Mandew, Campus Principal, Qwaqwa Campus, University of the Free State, South Africa; and,

- DrW.P. Wahl, Director: Student Affairs, University of the Free State, South Africa.

With the expansion of the group of section editors has also come a change to the structure of the editorial board to reflect better its de facto operations. The editorial board now has a threetier structure with the JSAA Editorial Executive sharing the day-to-day executive editorial and operational work. The Editorial Executive is made up of Prof. Teboho Moja as Editor-in-Chief, Dr Birgit Schreiber, and Prof. Thierry Luescher. It is supported administratively by Bronwin Sebonka who also manages the day-to-day online manuscript system. We welcome the new members and are grateful for their service.

The expanded list of section editors focuses on the editorial aspect of specific manuscripts. They help vet the incoming manuscripts, organise the double-blind peer review processes, and advise on the ways to proceed with a particular manuscript. Frequently, reviewers are drawn from our growing list of African and international scholars and expert practitioners. In this respect, we also envisage that our prestigious International Editorial Advisory Board will be renewed in the course of 2022 to ensure that the JSAA continues to have the best support from international experts from across the globe so as to progress on its quest to be the foremost academic journal dealing with the theory and practice of the Student Affairs domain in universities on the African continent.

\section{A New Publisher}

Volume 9 Issue 2 "Academic Advising" is the first issue of the JSAA produced with the University of Pretoria's Emerging Scholars Initiative Press (ESI Press). We are grateful to our publishing team led by Heather Thuynsma and Makone Maja for their work. Over the past decade, the JSAA has been served with distinction first by African Minds publishers and then African Sun Media. The appointment of ESI Press as new service provider is prompted by our move to the University of Pretoria. We are grateful to African Minds Publishers and African Sun Media for the sterling job they performed over the years.

\section{Online Submission, Editorial and Review System}

Finally, with the shift to Pretoria University we have moved our entire submission, editorial and publishing processes online. While the JSAA has always used the PKP open access journal management system, it has handled all submission, editorial and peer review processes until 
June 2021 using email. This was to accommodate colleagues (especially potential authors) who might lack the internet access to be able to successfully navigate the online journal management system. Covid-19, however, has leap-frogged many, voluntarily or not, into developing the capabilities to engage more successfully online. We have therefore taken the bold step to request all our authors, editors and reviewers to move into the online space and use the website's backend system for managing their interactions with each other. Bronwin Sebonka is ready to provide any support in this regard.

Many of these developments are prompted by the increasing number of manuscript submissions, which is a fantastic development: African Student Affairs is writing! We see more research about, from, and for Africa, across the entire scope of Student Affairs, Student Support and Services, and get submissions from a diversity of researchers and practitioners from our continent as well as overseas. We would like to continue to encourage African Student Affairs practitioners and researchers to contribute to the emerging knowledge base of African Student Affairs scholarship in our quest to professionalise Student Affairs in Africa.

\section{References}

Fussy, D. (2018). The status of academic advising in Tanzanian universities. KEDI Journal of Educational Policy, 15(1), 81-98.

Getachew, A. \& Daniel, G. (2016). Career Development Among Undergraduate Students of Madda Walabu University, South East Ethiopia. Journal of Student Affairs in Africa, 4(2), 25 37. DOI: $10.18820 /$ jsaa.v4i2.4

Janeke, B. (2021). Online Work Readiness Programme: Ready, Set Go! Journal of Student Affairs in Africa, 9(1), 119-133. DOI: 10.24085/jsaa.v9i1.1432

Luescher,T.M. (2017). From Student Enragement to Student Engagement:What is your theory of change? HSRC Review, 5(2), 13-15.

Maree,J.G. \& Molepo,J.M. (2004). Facilitating post-modern career counselling in the Limpopo province of South Africa: A rocky ride to hope. Australian Journal of Career Development, 13(3), 47-54.

Morgan, M. (2016). Improving the Student Experience in Higher Education.

http://www.improvingthestudentexperience.com

NACADA. (2006). Concept of academic advising. Manhattan, Kans., NACADA Clearinghouse of Academic Advising Resources. http://www.nacada.ksu.edu/Resources/Clearinghouse/ View-Articles/Concept-of-Academic-Advising.aspx

Nyar, A. (2021). The 'Double Transition' for First-Year Students: Understanding the Impact of Covid-19 on South Africa's First-Year University Students. Journal of Student Affairs in Africa, 9(1), 77-92. DOI: 10.24085/jsaa.v9i1.1429 
Ogude, N.A., Kilfoil, W.R. \& du Plessis, G. (2012).An institutional model for improving student retention and success at the University of Pretoria. The International Journal of the First Year in Higher Education, 3(1), 21-34.

Smith, L. (2020). Transition, mentoring and career guidance in higher education in the Global South. The Imprint of Education - Learning Activity 4: Literature Review. [Unpublished].

Strydom, J.F., Du Plessis, M. \& Henn, M. (2016). Using Evidence To Develop High Impact

Transition Programmes. Journal for New Generation Sciences, 14(3), 233-246. https:// hdl.handle.net/10520/EJC-6cf4d9ba4

Young, D.G. (2016). The case for an integrated approach to transition programmes at South Africa's higher education institutions. Journal of Student Affairs in Africa, 4(1), 17-32. DOI: 10.14426/jsaa.v4i1.142

Zozie, P.A. \& Kayira, P.B. (2012). Transition and Tertiary Education: A Case Study of Mzuzu University, Malawi. Research in Comparative and International Education, 7(4), 434-445. 